\title{
Management and Prevention of Enterprise Tax Risk
}

\author{
Maoliang Zhang \\ Shaanxi Provincial Administration College, Xi'an, Shaanxi, \\ ZhangmL6206@163.com
}

Keywords: Enterprise; Tax risk; Management; Prevention

\begin{abstract}
With the continuous improvement and perfection of China's market economic system and tax system, enterprises pay more and more attention to management and prevention of tax risk. If the enterprise can not be dealt with tax risk timely, it is likely to affect the normal operation of enterprises and then cause losses. Therefore, in the face of various tax risks, it is necessary for enterprises to study how to avoid, resolve and effectively prevent them in order to achieve the purpose of controlling tax risk. This paper analyzed the tax risk and its causes of the enterprise, and put forward the effective ways and measures to manage and prevent the tax risk of the enterprise, which has a certain reference significance for the enterprise to avoid the tax risk.

With the development of China's market economy, the market competitiveness of enterprises has been increasing, the transaction behavior and mode of enterprises have become more and more complicated. The state tax system has been gradually improved, the improvement of tax authorities and the strengthening of the collection management make enterprises face more and more tax problems, the various factors from internal and external enterprises are complex, leading to the increasing of enterprise tax risk, causing great losses to all aspects of the enterprise. Therefore, enterprise management and prevention of tax risk has become a top priority.
\end{abstract}

\section{The Importance of Preventing Enterprise Tax risk}

Enterprise tax risk refers to the fact that the tax-related behavior of the enterprise fails to comply with the tax law correctly and effectively, which leads to the possibility of interest loss of the enterprise in the future, It is the uncertainty of loss resulting from the difference between the actual performance of the enterprise in compliance with the tax law with the actual standard that should be reached. The tax risk of the enterprise mainly includes two aspects. On the one hand, the understanding of the tax law for enterprises is not deep enough, and the tax payment behavior can not be in accordance with the tax law, they have the the behavior of doing not tax, even tax less, so that the enterprise might be in face of being damaged and taxed, fine, plus late fees, penalties and other risks; on the other hand, the enterprise business behavior failed to accurately apply the tax law, did not make full use of the relevant tax policy, so pay more taxes, bear the unnecessary tax burden. Enterprises face various tax risks in the business process, the impact on the enterprise is a wide and deep, not only will not bring economic benefits to the enterprise, more likely to damage the company's reputation. Therefore, it is of great significance to strengthen the prevention of enterprise tax risk.

Firstly, establishing the concept of tax risk prevention is conducive to avoid enterprise tax risk. In the process of corporation operation, such as finding enterprise tax management problems timely, and take effective measures to deal with them, so that we can strengthen the level of enterprise management, reduce corporate tax burden reasonably and legitimately, and maximize the interests of enterprises.

Secondly, preventing and controlling tax risks can effectively reduce the economic losses of enterprises. Only regularly implement tax audit in the enterprise and strictly control tax risk, so as to maximize the implementation of tax according to law, and enterprises can are free from economic penalties of the tax authorities.

Again, carrying out tax risk prevention can reduce the credit losses. Taxation inaccuracies caused by enterprise tax behavior bring tax risk for enterprises, resulting in enterprises may violating national laws and regulations and even subject to administrative or economic discipline, which will 
have a very bad impact on corporate credit, and bring bad tax credit record to the enterprise. Through the prevention and control of tax risk, we can effectively avoid or reduce the risk of enterprise tax, maintain the good tax credit of enterprises.

Finally, tax risk may also result in the flow or lose of corporate management personnel, and may even criminalize corporate legal person and related persons. Through the prevention and control of tax risk, we can effectively avoid or reduce the tax risk of enterprises, and can try to avoid operation errors of the relevant management personnel, thereby reducing or eliminating the adverse effects on the management because of tax risk. Moreover, the prevention of tax risk also helps to create a good relationship between tax and corporate, coordinating the relationship between tax authorities and corporate tax levied. In short, enterprises carry out prevent tax risks, not only help to reduce unnecessary economic losses and credit losses, but also make the management manage the enterprises more comprehensively, so that enterprises maintain steady and rapid development.

\section{Analysis on the Causes of Corporate Tax Risk}

The causes of corporate tax risk usually includes internal factors and external factors. The internal factors mainly include the views of the management of the enterprise on the tax planning and the attitude towards the tax risk, the business model and business process, the business concept and development strategy, the establishment and implementation of the tax risk management mechanism, the enterprise information management status, the financial situation and the business effectiveness, etc .; External factors include the market economy and industrial policy, tax regulations or the applicability and integrity of local laws and regulations, the market competition environment and industry practices, etc.

(1) The tax risk caused by the enterprise's own management and operation factors

1. Tax risk caused by imperfect corporate internal control system. Affected by the traditional concept, many companies do not really recognize the importance of tax internal control system, let alone the formulation and implementation of the tax internal control system. The main performance is that partial enterprises allow financial staff to take several positions in order to streamline the establishment of institutions and reduce costs, especially the phenomenon of accounting and tax dual part-time is more common. Some enterprises solve the tax problem through the account adjustment, not only the accounting data on the economic business can not be properly reflected, and even some will be punished because the tax authorities treat the behaviors belong to tax evasion. And some corporate tax staff have poor professionalism and professional ethics, lack of responsibility, make many mistakes in daily simple tax returns, tax calculation and other basic work, bring potential risk to the enterprises.

2. Tax risk brought by business diversification. The globalization of economic development has led to an increasing number of enterprises, more and more industries involved in the business, and thus the more taxes are involved, the complexity of business activities has greatly increased the tax risk. In addition, with the increase in the number of mergers and acquisitions, due to the asymmetry of information, enterprises often do not fully investigated the tax situation of the enterprises in the mergers or acquisitions. After completion of the acquisition or merger, only to find the enterprises have tax problems, which will bring great losses to the enterprise. For example, if the merged enterprise exists tax evasion problem in the previous year, once discovered, the tax authorities will require the enterprise to bear the supplementary taxes and pay the amount of the fines; if the acquired enterprise has completed depreciation of the fixed assets before the acquisition, tax deduction before income tax will increase the tax burden of enterprises.

3. Tax risk caused by improper tax planning. Some enterprises did not set up a tax post or set up a tax position but only in accordance with the provisions of the law to fulfill the tax obligations, do not apply the concept of tax planning to the actual work, do not carry out the planning for prior, processing and after of the enterprise tax, do not play its essential effect. Some enterprises carry out tax planning, but the tax planning just focus on subjective judgments, there is no deep understanding and analysis of the policy to produce deviation, resulting in tax planning did not play a role in reducing corporate tax burden. 
4. Tax risk caused by tax risk early warning mechanism has not yet been established. Tax risk is uncertain, but if the tax risk is scientifically managed and evaluated, the law can be found. The practical experience shows that the complete tax risk early warning mechanism can effectively buffer and avoid the potential tax risk of the enterprise. However, some of enterprises and groups in China have not yet established a complete tax risk early warning mechanism, some small businesses even pay less attention to the establishment of risk early warning mechanism.

(2) Tax risk caused by external factors

1. Tax risk caused by complex tax law system. China's tax law system is complex and more taxes, some of the relevant laws, regulations and regulatory documents are more general and fuzzy, so that there is an understanding of the deviation on the taxation between the two sides. At the same time, different levels of tax laws are also different, affecting the tax behavior of enterprises to some extent, increasing corporate tax risk. China's tax law is a statutory law, the tax authorities hold the final interpretation of the tax, the understanding of law-executor to legal provisions is legal basis of determination of the final legal responsibility, while the taxpayer must be at a disadvantage position, which also increased the tax risk of the enterprise. In addition, China's tax reform and policy changes continually, making enterprises continue to adjust the tax, once the lack of timely controlling tax policy changes, it will inevitably bring tax risk to the enterprise.

2. Tax administration law enforcement is not standardized, the audit is not enough. First of all, China's tax administration system is more complex, tax-related behaviors of enterprise often involve a number of tax law enforcement subjects, but different tax subjects have different understanding on the same tax-related behavior, which necessarily results in the different treatment to tax-related behavior. Secondly, the level of tax law enforcement officers will affect their understanding of the tax law and the handling of business, which also virtually increase the tax risk of enterprises; Finally, in the practice of tax collection and management, due to the restriction of a variety of factors, the tax authorities are often working only for the reported cases or random checks, making some enterprises produce the fluke mind to evade taxes, increasing the tax risk of enterprises, once identified, will inevitably face severe penalties.

\section{The Countermeasures of the Management and Prevention of Corporate Tax Risk}

Tax risk can bring huge losses to the enterprise, but we do not need to treat corporate tax risk as a monster, while we should manage and prevent corporate tax risk through the following channels.

\section{(1) Establish the Tax Internal Control System}

Effective tax internal control is a system guarantee for controlling tax risk. Tax internal control should comprehensively take the five aspects of tax control environment, risk assessment, control activities, information and communication and internal supervision into account. The internal control environment mainly set up enterprise tax structure, corporate culture and internal audit institutions. The establishment of internal institutions must be reasonable to meet the actual tax treatment needs in production and operation. The key point is to identify the risk in the tax risk assessment, to find out the influencing factors of the enterprise tax risk, to summarize the key points of the enterprise risk control, and then we should consider the possibility and the degree of influence of the risk so as to determine the risk strategy. After the completion of the risk assessment, tax risk case database should be established to provide data support for future tax risk assessment. The enterprise should clearly stipulate the control of the internal activities, including the organization planning control, the authorization control, the document record control, the performance control, the division of labor control, the examination and approval control, the accounting system control and so on. Enterprises should improve the internal information communication mechanism to achieve effective communication of corporate tax information. For the supervision of corporate tax, we should adhere to continuous supervision under the implementation of internal tax control, carry out targeted checks in the case of specific aspects of internal control under the changes of internal and external environment to reduce the tax risk of enterprises. 


\section{(2) Improve the Business Level of Tax-Related Personnel}

Improving the business level of tax-related personnel is basis to prevent tax risk. Enterprise tax risk management work is inseparable from a large number of high-quality tax management personnel, enterprises must build the tax-related team with a strong professional knowledge, good professional ethics. Business managers must pay attention to the importance of talent, continue to introduce and train high-quality tax personnel, and give employees a broader space for development, timely carry out targeted training for tax personnel to improve their professional skills. At the same time, companies must give employees more incentives to ensure the stability of the team.

\section{(3) The Implementation of Scientific and Reasonable Tax Planning}

Scientific and reasonable tax planning is an important way for enterprises to carry out tax risk prevention. Legal tax is the ultimate goal of the enterprise. Tax-related personnel should grasp the state tax system in a timely manner, pay attention to tax preferential policies, comprehensively considerate the tax planning program in the base of tax laws and preferential policies, screening out the lowest tax risk program.

\section{(4) Legalization of Tax-Related Work Processes}

Firstly, company should regularly update tax management reports. Tax management reports mainly include: 1 . Tax forecasting. The tax forecasting is established based on coping strategy of the expected management and the expected constant tax environment, reflecting the expected tax status in the tax statement; 2. Tax work plan report. Tax work plan report is used to describe the measure regulation, work content and objectives setting in the tax work in this one year; 3 . Annual real tax report. Making in-depth analysis on the annual real tax report, enterprises can better understand the points of tax risk in operational, and take the appropriate control and preventive measures for tax risks. Secondly, the establishment of the exception reporting system. The exception reporting system mainly describes the situation outside the conventional tax affairs, such as the effect by the change of the tax policy and the change of the tax law on the enterprise. The degree of the influence on the enterprise in these conditions needs to be analyzed and evaluated accurately in the exception report so as to achieve the purpose of prevention of tax risk.

\section{(5) Focus on Tax Policy Research}

The tax administration department of the enterprise should pay attention to the national macroeconomic trend, take care of the adjustment of the industrial policy, take the change of the accounting system into account, collect and collate the tax information related to the enterprise, and carry out careful research on the tax policy used by the enterprise, which not only reduce and prevent the tax risk caused by changes in tax policy, but also can reduce risk caused by the enterprise using the wrong tax policy. In addition, the enterprise tax administration department should strengthen the contact and communication with the tax authorities, keeping abreast of the tax policy, timely getting the guide of tax authorities, to ensure that their understanding of the tax policy consistent with the tax authorities, thus reduce corporate tax risk.

In short, the management and prevention of corporate tax risk has become a new subject that tax collection agencies and taxpayers must face. In order to reduce the tax risk, enterprises need to gradually improve the tax risk management system, combining the tax risk management and prevention with the enterprise development strategy, and make the systemic plan, so that corporate tax risk can be controlled in a certain range, they are of great significance for the maintenance of standardized tax order, protecting the country's tax benefits and the interests of taxpayers.

\section{References}

[1] Chen Yu. Enterprise tax risk and corresponding prevention management strategy [J]. Marketing, 2016, (2): 129-130.

[2] Hangzhou State Taxation Bureau Task Force, Zhang Jikang. International Experience and Reference of Tax Risk Management for Large Enterprises [J]. Foreign Taxation, 2015, (6): 34-39.

[3] Zhang Fan. Discussion on corporate tax risk prevention based on internal control [J]. Reform and Opening, 2015, (12): 76-77. 
[4] Yang Yanjing. Discussion on corporate tax risk and prevention strategy [J]. Finance and Economics (Academic Edition), 2014, (05): 219-220.

[5] Wang Bo, Shi Anna. Re-understanding of risk in risk management theory[J]. Business Modernization, 2014, [11]: 6s-660.

[6] An Tifu, Yang Jinliang. research on tax policy to promote the development of small and micro enterprises [J]. Economic and Management Review, 2012.

[7] Xie Xuren. Finance and taxation policy to promote the development of small and medium enterprises [J]. Administrative reform, 2012.

[8] Sun Jinshui. Strategy optimization of developing the external environment for China's small and medium enterprises [J]. Journal of Zhongzhou University, 2013.

[9] Wang Jianing, Luo Chongpu. China's small micro-enterprise development policy choices and overall trends [J]. Reform, 2012.

[10] Zhang Jinrui. Development report of small and medium enterprises of Zhejiang Province in 2013 [M]. Zhejiang Industrial and Commercial University Press, 2013.

[11] Cai Yong, Ma Yuanyuan. Tax policy international experience on promoting the development of small micro-enterprise [J]. Friends of Accounting, 2014,10: 85-87. 